MINING

UDC 622.271

N. A. Nemova ${ }^{1}$, Cand. Sc. (Tech.), orcid.org/0000-0002 -5050-611X, D. Tahanov ${ }^{2}$, Cand. Sc. (Tech.), orcid.org/0000-0002-2360-9156, B. Hussan ${ }^{2}$, orcid.org/0000-0003-0996-348X, A. Zhumabekova ${ }^{2}$, orcid.org/0000-0002-1501-5382

\section{https://doi.org/10.33271/nvngu/2020-2/017}

1 - Mining Institute of Siberian Branch of the Russian Academy of Sciences, Novosibirsk, the Russian Federation, e-mail: nemova-nataly@mail.ru

2 - Karaganda State Technical University, Karaganda, the Republic of Kazakhstan, e-mail: takhanov80@mail.ru

\title{
TECHNOLOGICAL SOLUTIONS DEVELOPMENT FOR MINING ADJACENT ROCK MASS AND PIT RESERVES TAKING INTO ACCOUNT GEOMECHANICAL ASSESSMENT OF THE DEPOSIT
}

Purpose. The assessment of options for opening and mining the upper tier of Oleniy Ruchey apatite- nepheline deposits and technological solutions development taking into account geomechanical calculations of open pit slopes and benches stability, both on the marginal contour and when changing the design values of the slope parameters, open pit benches and the stability safety factor to establish the marginal maximum accepted under the condition of the values stability.

Methodology. Searching for technological solutions of mining is based on the method of mining and geometric analysis of the deposit upper tier, comparison, generalization, systematization, analytical calculations, 3D parametric modeling, three-dimensional numerical modeling of stress-strain state and the rock mass stability by the finite element method.

Findings. According to the research results, the optimal development of mining operations has been proposed for an option providing for the minimum overburden ratio. The parameters of the highwall slopes and their elements on the marginal contour and the development of the deposit are recommended according to the option that provides the maximum possible involvement in the development of the adjacent rock mass and pit reserves mining within the existing limits of the open pit mining tap.

Originality. It consists in feasibility evaluation of using a rational technology for the development of mining operations according to the option that provides for the minimum overburden ratio and possible mining development schemes for mining open pit reserves with an assessment of the possibility of internal dumping during the development of an open pit.

Practical value. The calculations show that for the conditions of a lying side, the normative factor of the slope stability on the marginal contour can be ensured only if they are bank slopes worked along the weakening surfaces, whose cutting should not be permitted.

Keywords: edge, slope, adjacent rock mass, pit reserves, open pit reserves, stress-strain state, stability, development system

Introduction. The relevance of the work is caused by the need to perform safely mining operations in open pits of a considerable depth. Increasing production volumes is possible with significant deepening, and to reduce overburden volumes, it is necessary to steepen the sides of the slopes and benches. To solve this issue, it is necessary to know the geomechanical situation of the benches and slopes, both on the marginal contour and when changing their basic parameters: the height and the angle of inclination.

In the Khibiny a large deposit of apatite nepheline ores called Oleniy Ruchey, located in the south-eastern part of the Khibiny massif, is being developed [1,2]. The productive zone has a complex multi-tiered structure, due to the alternation of apatite-nepheline ores, trachytoid urtites, ijolites, Melteigites, massive urtites and juvits, nepheline syenites, as well as outliers of more ancient ristschorrits in the section of the layer-like bodies. At present the development of the field is carried out by the open method [3, 4].

The slope stability is mainly affected by the structuraltectonic pattern of the marginal massifs formed due to the development of reserves [5, 6].

(C) Nemova N.A., Tahanov D., Hussan B., Zhumabekova A., 2020
Comprehensive geological studies of the Oleniy Ruchey apatite-nepheline deposit show the presence of the Main Fault that is an intensely tectonized zone, occurring subconcordantly to the ore deposit (cutting it at an acute angle), complicated by numerous branching feathering disorders and accompanied by intense oxidation with participation of meteoric waters and cataclasis [7]. The angle of incidence of the Main Fault is approximately $40-45^{\circ}$.

The advanced operational exploration to identify new ore bodies or ore deposits is carried out with the aim of operational and long-term planning the mining operations, as well as to obtain the data of safe mining and stripping operations, ensuring the most complete extraction of the main reserves and co-located ore bodies. New ore bodies can be identified both in the adjacent rock mass zone and outside the marginal contour of the pit.

On the other hand, the analysis of the fields operated by the open or combined method shows that the reserves in the slopes reach $45 \%$ of all the reserves located both in the adjacent rock mass zone and outside the marginal contour of the open-pit. However, experience shows that not all enterprises work out such reserves; in most cases they are left. But the development of these reserves would make it possible to increase 
the efficiency of development and completeness of extraction during the mining of ore deposits [1,2].

Searching, selecting and justifying the options for the development of newly discovered ore bodies, which are both in the adjacent rock mass zone and in the pit reserves with the combined method of their development, ensuring their effective and safe development with the greatest completeness of extraction is an urgent task at present.

The scope of research dealing with the final extraction of reserves located in the marginal zone necessitates their expansion in order to develop a regulatory framework and documents for the design of rational development systems and stripping schemes for adjacent rock mass and sub-career reserves. Today there are no methodologies for selecting the design of development systems for adjacent rock mass and pit reserves by the open, underground or combined way; a rational procedure for developing such reserves has not been substantiated.

The limited development of adjacent rock mass and pit reserves is closely related to geomechanical conditions. Changing the stress-strain state (SSS) of the massif during mining operations in the adjacent rock mass zone leads to changing the position of the sliding surface. On the other hand, the final extraction of reserves in the specified zone begins after the slope has been put into the final position. Consequently, when selecting a technology for final extraction of reserves, geomechanics becomes paramount.

The adjacent rock mass reserves, which are subject to both open and underground final extraction, located beyond the marginal contour of the open-pit mine, are characterized by a more complex geological structure, the presence of isolated sections, and dispersal of reserves along the perimeter of the open pit. The areas of the field that are subject to underground final extraction are, as a rule, confined to lenses, zones of tectonic disturbances, deposits with a low content. The mined ore zones are often represented by local ore deposits, areas with inconsistent thickness, with small sizes of strike and dip, low quality, and sometimes related to off-balance reserves.
When designing the technology for final extraction of adjacent rock mass and pit reserves, the greatest difficulties arise because their development causes a violation of stability of both the pit slopes and benches.

Methods. When performing a detailed mining and geometric analysis of the upper tier of the deposit, the volumes of ore and overburden outside the open-pit project contour have been calculated using the method of parallel sections. The essence of the method consists in splitting the deposit with vertical sections (cuts), the distance between which is from $20 \mathrm{~m}$ to $80 \mathrm{~m}$. To calculate the reserves, the mineral deposit has been divided into separate calculating blocks, the boundaries of which have been flat sections. At the same time, the total volume of ore amounted to 3,840 thousand $\mathrm{m}^{3}$, including pit ore reserves of 2,756 thousand $\mathrm{m}^{3}$ and adjacent rock mass reserves of 1084 thousand $\mathrm{m}^{3}$.

Options of mining operations development schemes with final extraction of reserves. Possible development schemes of mining in the final extraction of pit reserves have been analyzed. There have been considered and studied possible options of schemes of opening and final extraction of reserves in the adjacent rock mass zone with observance of the conditions for the development of mining operations within the boundaries of the mining allotment. Technological solutions for developing adjacent rock mass and pit reserves are presented in Table 1.

For each of the options presented, in order to select a rational option for mining, there have been determined overburden volumes, horizons of ore divided into pit and adjacent rock mass ores, as well as overburden ratio for comparison with the overburden boundary coefficient, determined from the condition of the equal cost of ore mining by underground and open methods (Table 2).

Analyzing the obtained values of total ore volumes divided into the pit and adjacent rock mass reserves (Table 2), we conclude that the final extraction of reserves under option 1 makes $44 \%$ of the total reserves, including $33 \%$ of the pit and $72 \%$ of adjacent rock mass reserves; under option 2 it is $23 \%$ of the

Table 1

Rational options of mining operations development

\begin{tabular}{|c|c|c|c|c|}
\hline No & & $\begin{array}{l}\text { General characteristic of possible schemes } \\
\text { of stripping and final extraction of adjacent } \\
\text { rock mass and pit reserves }\end{array}$ & Advantages & Drawbacks \\
\hline 1 & Option 1 & $\begin{array}{l}\text { It provides the maximum possible } \\
\text { involvement in the development of } \\
\text { adjacent rock mass and pit reserves } \\
\text { within the existing boundaries of the } \\
\text { mining allotment from the condition of } \\
\text { providing an access from the surface to } \\
\text { the lowest horizon }\end{array}$ & $\begin{array}{l}\text { As a result of the studies, it has been } \\
\text { revealed that it is possible to descend as far } \\
\text { as possible in the north-eastern and } \\
\text { south-western parts of the deposit with } \\
\text { open pit mining, and to aximize the ore } \\
\text { reserves development in the adjacent rock } \\
\text { mass zone }\end{array}$ & $\begin{array}{l}\text { To ensure the given production, it } \\
\text { is necessary to remove the entire } \\
\text { volume of excavated overburden } \\
\text { and to lay it in external dumps }\end{array}$ \\
\hline 2 & Option 2 & $\begin{array}{l}\text { It provides the maximum possible, as in } \\
\text { option } 1 \text {, involvement in the development } \\
\text { of adjacent rock mass reserves and part of } \\
\text { the pit reserves of ore bodies traced in the } \\
\text { south-western part of the mine field with } \\
\text { the depth of } 15-45 \mathrm{~m}\end{array}$ & $\begin{array}{l}\text { As a result of the studies, the following has } \\
\text { been revealed: } \\
\text { 1. It is possible to pick up adjacent rock } \\
\text { mass ore reserves traced in the laying side } \\
\text { of the ore deposit as far as possible. } \\
\text { 2. From the pit reserves in mining there } \\
\text { are involved only ore bodies with } \\
\text { deepening the project boundaries in this } \\
\text { part of the mine field to } 15-45 \mathrm{~m} \text {. } \\
\text { 3. In the north-eastern part of the mine } \\
\text { field its technical boundary does not } \\
\text { change along the bottom and along the } \\
\text { western slope }\end{array}$ & $\begin{array}{l}\text { To ensure the given production, the } \\
\text { entire volume of rock overburden } \\
\text { being removed can be laid in the } \\
\text { internal dump that can be formed } \\
\text { in the north-eastern part of the } \\
\text { mine field, whose deepening is not } \\
\text { stipulated by the option }\end{array}$ \\
\hline 3 & Option 3 & $\begin{array}{l}\text { It provides the development of adjacent } \\
\text { rock mass and a part of the pit reserves in } \\
\text { the south-western part of the mine field, } \\
\text { which are also to be opened, as in option } 2 \text {, } \\
\text { and in the north-east part, the pit reserves } \\
\text { are mined with the open put deepening }\end{array}$ & $\begin{array}{l}\text { To ensure the given production, the } \\
\text { excavated overburden rocks are to be laid } \\
\text { partly in the developed space with filling } \\
\text { its southern and northern ends up to the } \\
\text { hor. }+240 \text { and partly to the external dump }\end{array}$ & \\
\hline
\end{tabular}


Extracted ore and overburden volumes in options

\begin{tabular}{|l|c|c|c|c|c|}
\hline \multirow{2}{*}{ Name } & \multirow{2}{*}{$\begin{array}{c}\text { Overburden volumes, } \\
\text { thousand } \mathrm{m}^{3}\end{array}$} & $\begin{array}{c}\text { Overburden ratio, } \\
\mathrm{m}^{3} / \mathrm{m}^{3}\end{array}$ & $\begin{array}{c}\text { Total horizons ore } \\
\text { volumes, thousand } \mathrm{m}^{3}\end{array}$ & Pit reserves & Adjacent rock mass reserves \\
\cline { 5 - 6 } & 29650 & 17.3 & 1710 & 922 & 788 \\
\hline Option 1 & 7800 & 8.9 & 880 & 92 & 788 \\
\hline Option 2 & 8550 & 8.2 & 1039 & 251 & 788 \\
\hline
\end{tabular}

total reserves, including $3 \%$ of the pit and $72 \%$ of adjacent rock mass ores; in option 3 it is $27 \%$, including $9 \%$ of the pit and $72 \%$ of the adjacent rock mass reserves. It follows that under option 1, it is possible to maximally involve adjacent rock mass and pit reserves in the mining within the existing boundaries of the mining allotment of the open-pit. On the other hand, mining options have a limiting overburden ratio that is adopted equal to $12 \mathrm{~m}^{3} / \mathrm{m}^{3}$ for the conditions of mining of this nepheline-apatite ore deposit.

As it can be seen from Table 2, following the analysis of the three considered possible options for opening and preparing schemes of the adjacent rock mass and pit reserves at the Oleniy Ruchey deposit, it can be concluded that the most rational is option 3 , in which the overburden ratio is $8.2 \mathrm{~m}^{3} / \mathrm{m}^{3}$ (Table 2 ), but with a smaller share of production reserves in the adjacent rock mass zone.

Justification of rational scheme of stripping and preparing procedure. According to the conditions of the terrain in the open pit, the upland part is marked up to $315 \mathrm{~m}$ and the deep part is below $315 \mathrm{~m}$. According to the decisions made during implementation of option 3, it has been proposed to strip the open-floor horizons of the open pit with semi-trenches and the deep part in the south-east side of the open pit with the system of permanent cross-overs. It is rational to produce the reserves located in the adjacent rock mass zone in the following order:

1. The first stage. Developing the maximum possible volume of the adjacent rock mass reserves with $15 \mathrm{~m}$ deepening. The duration of the stage will be 2 years of exploitation of the open pit. In parallel, it is necessary to carry out operations related to the construction of a mine for the development of the pit reserves.

2 . The second stage. The operations having been completed, the mine is put into operation and the pit reserves are finally extracted by the underground method.

Geomechanical assessment of slopes and their elements stability accepted in the working project. When designing the technology of excavation of adjacent rock mass and pit reserves, the greatest difficulties arise because their development causes a violation of stability of both the pit benches and the slope.

The strength characteristics of the rocks of the Oleniy Ruchey apatite-nepheline deposit obtained by geologists when testing the samples are given in Table 3.

The calculated strength characteristics of the rock massif are presented in Table 4, which presents characteristics of rocks, both in the weathering zone and below it.

Table 3

Strength characteristics of the rocks

\begin{tabular}{|c|c|c|c|c|c|c|c|c|}
\hline \multirow{2}{*}{ Rock } & \multicolumn{2}{|c|}{$\begin{array}{l}\text { Ultimate strength, } \\
\mathrm{MPa}\end{array}$} & \multirow{2}{*}{$\begin{array}{l}\text { Brittleness } \\
\text { ratio, un. }\end{array}$} & \multicolumn{2}{|c|}{$\begin{array}{l}\text { Internal friction } \\
\text { angle, degree }\end{array}$} & \multirow{2}{*}{$\begin{array}{l}\text { Cohesion in the } \\
\text { sample } C_{o} \text {, MPA }\end{array}$} & \multicolumn{2}{|c|}{ Hardness ratio, un. } \\
\hline & compression & tension & & $j_{o}$ & $j$ at $0.5 \sigma_{c o m}$ & & $\begin{array}{c}\text { Acc. to } \\
\text { M. Protodyakonov }\end{array}$ & Acc. to L. Baron \\
\hline Ristschorrits & 204 & 7.4 & 28 & 69 & 41 & 19.9 & 20 & 9 \\
\hline Ristschorrits-juvits & 98 & 3.9 & 25 & 68 & 40 & 10.4 & 10 & 6 \\
\hline Juvits & 199 & 7.4 & 27 & 68 & 41 & 19.7 & 20. & 9 \\
\hline Juvits, leucocratic & 110 & 6.0 & 18 & 64 & 39 & 13.7 & 11 & 7 \\
\hline Urtites & 111 & 4.5 & 25 & 67 & 40 & 11.3 & 11 & 6 \\
\hline Monchiquites & 276 & 16.6 & 17 & 62 & 39 & 34.7 & 28 & 13 \\
\hline
\end{tabular}

Table 4

Calculated strength characteristics of the rock massif

\begin{tabular}{|c|c|c|c|c|c|c|c|c|c|}
\hline \multirow{3}{*}{ Rock lithotypes } & \multirow{3}{*}{$\begin{array}{c}\text { Volume } \\
\text { weight, } \\
\mathrm{t} / \mathrm{m}^{3}\end{array}$} & \multirow{3}{*}{$\begin{array}{c}\text { Cohesion in } \\
\text { the sample, } \\
t / \mathrm{m}^{2}\end{array}$} & \multirow{3}{*}{$\begin{array}{c}\text { Structural } \\
\text { weakening ratio }\end{array}$} & \multicolumn{3}{|c|}{ Cohesion, $\mathrm{t} / \mathrm{m}^{2}$} & \multicolumn{3}{|c|}{ Internal friction angle, degree } \\
\hline & & & & \multicolumn{3}{|c|}{$\begin{array}{l}\text { Taking into account stability safety } \\
\text { factor }\end{array}$} & \multicolumn{3}{|c|}{$\begin{array}{l}\text { Taking into account stability } \\
\text { safety factor }\end{array}$} \\
\hline & & & & 1.0 & 1.3 & 1.5 & 1.0 & 1.3 & 1.5 \\
\hline \multicolumn{10}{|c|}{ Primary rocks } \\
\hline Ristschorrits & 2.76 & 2028 & \multirow[t]{4}{*}{$0.0163 / 0.0420$} & $33.0 / 85.1$ & $25.3 / 65.4$ & $22.0 / 56.7$ & 41 & 33.7 & 30.0 \\
\hline Ristschorrits-juvits & 2.70 & 1061 & & $17.3 / 44.5$ & $13.3 / 34.2$ & $11.53 / 29.6$ & 40 & 32.8 & 29.2 \\
\hline Juvits & 2.70 & 2008 & & $32.7 / 84.3$ & $25.1 / 64.8$ & $21.8 / 56.2$ & 41 & 33.7 & 30.0 \\
\hline Urtites & 2.66 & 1151 & & $18.7 / 48.3$ & $14.3 / 37.1$ & $12.4 / 32.2$ & 40 & 32.8 & 29.2 \\
\hline \multicolumn{10}{|c|}{ Strength characteristics on the weakening surfaces } \\
\hline & & & & 10 & 7.6 & 6.6 & 25 & 19.7 & 17.2 \\
\hline
\end{tabular}


The magnitude of seismicity is determined by the corresponding schematic maps of SNiP II-7-81*. For the conditions of the area of the deposit, the seismicity coefficient is taken as $m=0.025$ (7 points) [8,9].

Results of calculating parameters of slope and bench stability on marginal contour. The main criterion for assessing the working slope and bench stability is the observance of the equilibrium condition of shearing and confining forces [9], or the excess of the confining forces over the shearing forces acting on the most stressed surface in the adjacent rock mass massif.

In assessing stability of slopes and their elements on the marginal contour, the stability safety factor should, in accordance with the recommendations of the current regulatory documentation [9], be:

- not less than $\eta=1.3$ for the slopes of the open pit;

- not less than $\eta=1.5$ for benches composed of fractured rocks, with the standing period up to 5 years and at least $\eta=$ $=2.0$ for benches with the standing period more than 5 years.

The calculation of stability of the slopes has been performed in accordance with the "Guidelines ...". The calculation of stability for determining the parameters of the slopes in the absence of unfavorably oriented surfaces of weakening have been performed by the method of algebraic addition of forces according to the V scheme [9]. The calculations have used the calculated strength properties of rocks of the adjacent rock mass massifs (Table 4). The sliding surface is adopted as smooth and curvilinear, close in shape to circular-cylindrical.

The results of calculating the stable angles of the slopes on the marginal contour are given in Table 5, taking into account the stability safety factor $\eta=1.3$. The parameters of the slopes are valid in the absence of weakening surfaces in the adjacent rock mass massif. In the presence of weakening surfaces with a fall in the working, it is necessary to roll back strictly along these surfaces.

The results of the checking calculations of the stability safety of the slopes on the marginal contour, corresponding to the design solutions along the profile lines 29 and 33 are given in Table 6. The calculations are valid under the condition that there are no weakening surfaces in the adjacent rock mass massifs, in the presence of weakening surfaces with a fall in the working, the slopes are to be rolled back along these surfaces.

The checking calculations of the slope stability on the design marginal contour and those in option 3 (Table 6) show that their stability is mainly provided by the normative factor of stability safety $(\eta=1.3)$, with the exception of the northwest side sections in the hanging wall (gray).

Calculating overburden bench slope stability. There have been calculated overburden benches in weathered and unweathered rocks of the hanging walls, as well as those in weathered and unweathered rocks of the lying side, taking into account the complicating factors, namely the surface weakening, the water content, seismicity and in their absence.

As it is seen from Table 7, according to the calculations, the overburden bench stability with a standard stability factor $\eta=1.5$, taking into account the seismicity of the region and the groundwater level:

a) is ensured with the following design parameters:

- in weathered rocks for hanging wall benches (in the absence of weakening surfaces in the adjacent rock mass massif) $H=30 \mathrm{~m}, \alpha=60^{\circ}$ (Fig. 1);

- in unweathered rocks for hanging wall benches (in the absence of weakening surfaces in the adjacent rock mass massif) $H=30 \mathrm{~m}, \alpha=70^{\circ}$ (Fig. 2);

b) is not ensured when the angles of overburden benches become steeper:

- in weathered rocks for hanging wall benches (in the absence of weakening surfaces in the adjacent rock mass massif) $-H=45 \mathrm{~m}, \alpha=55^{\circ}$ (the parameters of tripled benches on the marginal contour) (Fig. 3);

- in unweathered rocks for hanging wall benches (in the absence of weakening surfaces in the adjacent rock mass massif) at $H=45 \mathrm{~m}$ and $\alpha=65^{\circ}$ (Fig. 4, a), at $H=30 \mathrm{~m}$ and $\alpha=90^{\circ}$ (Fig. $4, b$ ) (the parameters of the tripled benches on the marginal contour);

\section{c) is not ensured:}

- in weathered and unweathered bedding rocks.

After analyzing the results obtained from Table 7, comparing with the standard value $\eta$, we have established the following:

1. A detailed study of the geomechanical situation in the rock massif of the hanging wall, without taking into account the complicating factors, with high probability can indicate a stable position of the benches on the marginal contour with their design values, but taking into account the complicating factors, the change in design values leads to decreasing the stability safety below the standard value [10].

2. Increasing the design slope angles of the bench with its height of $30 \mathrm{~m}$ in the hanging wall rocks to $80-90^{\circ}$ in the zone

Table 5

Results of calculating stable angles of the slopes on the marginal contour depending on the slope height

\begin{tabular}{|l|c|c|c|c|c|c|c|}
\hline Slope height $\mathrm{H}, \mathrm{m}$ & 50 & 100 & 150 & 200 & 250 & 300 & 350 \\
\hline Angle of the slope inclination $\alpha$, deg. & 54 & 50 & 50 & 49 & 49 & 48 & 45 \\
\hline
\end{tabular}

Table 6

Summary table of calculating the slope stability safety factor

\begin{tabular}{|l|c|c|c|c|c|c|c|c|c|c|c|c|c|c|}
\hline \multicolumn{1}{|c|}{ Profile Line No. } & \multicolumn{9}{|c|}{ Pr.L.29 } & \multicolumn{5}{c|}{ Pr.L.33 } \\
\hline \multicolumn{1}{|c|}{ Slope orientation } & \multicolumn{4}{|c|}{ NW } & \multicolumn{3}{|c|}{ SE } & \multicolumn{3}{c|}{ NW } & \multicolumn{3}{c|}{ SE } \\
\hline Slope height, $\mathrm{m}$ & 328 & 282 & 165 & 43 & 283 & 207 & 58 & 323 & 301 & 60 & 11 & 87 & 199 & 57 \\
\hline Slope inclination angle, degree & 41 & 50 & 53 & 75 & 37 & 42 & 65 & 44 & 49 & 78 & 43 & 38 & 36 & 59 \\
\hline Sliding surface & S1 & S2 & S3 & S4 & S1 & S2 & S3 & S1 & S2 & S3 & S1 & S2 & S3 & S4 \\
\hline Stability safety factor & $>1.5$ & $>1.5$ & $>1.5$ & 1.31 & $>1.5$ & $>1.5$ & 1.38 & $>1.5$ & 1.51 & 1.26 & $>1.5$ & $>1.5$ & $>1.5$ & $>1.5$ \\
\hline $\begin{array}{l}\text { Stability safety factor considering } \\
\text { seismicity of the region }\end{array}$ & $>1.5$ & 1.49 & $>1.5$ & 1.27 & $>1.5$ & $>1.5$ & 1.33 & $>1.5$ & 1.44 & 1.22 & $>1.5$ & $>1.5$ & $>1.5$ & 1.46 \\
\hline $\begin{array}{l}\text { Stability safety factor considering the } \\
\text { ground water level }\end{array}$ & 1.48 & 1.39 & 1.37 & - & $>1.5$ & $>1.5$ & - & 1.45 & 1.37 & - & - & $>1.5$ & $>1.5$ & - \\
\hline $\begin{array}{l}\text { Stability safety factor considering seismicity } \\
\text { of the region and the ground water level }\end{array}$ & 1.41 & 1.33 & 1.30 & - & $>1.5$ & $>1.5$ & - & 1.38 & 1.31 & - & - & $>1.5$ & $>1.5$ & - \\
\hline
\end{tabular}


Summary table of calculating the benches stability safety factor

\begin{tabular}{|c|c|c|c|c|c|c|c|c|c|c|c|c|c|}
\hline \multirow[b]{2}{*}{ Slope height, $\mathrm{m}$} & \multicolumn{2}{|c|}{$\begin{array}{c}\text { Slope benches in } \\
\text { weathered rocks of the } \\
\text { hanging slope }\end{array}$} & \multicolumn{3}{|c|}{$\begin{array}{l}\text { Slope benches in } \\
\text { unweathered rocks of } \\
\text { the hanging wall }\end{array}$} & \multicolumn{4}{|c|}{$\begin{array}{c}\text { Slope benches in } \\
\text { weathered rocks of the } \\
\text { lying wall }\end{array}$} & \multicolumn{4}{|c|}{$\begin{array}{c}\text { Slope benches in } \\
\text { unweathered rocks of the } \\
\text { lying wall }\end{array}$} \\
\hline & 30 & 45 & 30 & 45 & 30 & 30 & 30 & 45 & 45 & 30 & 30 & 45 & 45 \\
\hline Slope inclination angle, degree & 60 & 55 & 70 & 65 & 90 & 60 & 80 & 55 & 80 & 70 & 80 & 65 & 80 \\
\hline Stability safety factor & $>1.5$ & $>1.5$ & $>1.5$ & $>1.5$ & 1.32 & 1.37 & 0.87 & 1.18 & 0.78 & 1.44 & 0.97 & 1.19 & 0.78 \\
\hline $\begin{array}{l}\text { Stability safety factor considering } \\
\text { seismicity of the region }\end{array}$ & $>1.5$ & $>1.5$ & $>1.5$ & $>1.5$ & 1.27 & 1.32 & 0.84 & 1.14 & 0.75 & 1.4 & 0.94 & 1.15 & 0.75 \\
\hline $\begin{array}{l}\text { Stability safety factor considering } \\
\text { the ground water level }\end{array}$ & $>1.5$ & $>1.5$ & $>1.5$ & 1.48 & 1.24 & - & - & - & - & - & - & - & - \\
\hline $\begin{array}{l}\text { Stability safety factor considering } \\
\text { seismicity of the region and the } \\
\text { ground water level }\end{array}$ & $>1.5$ & 1.44 & $>1.5$ & 1.41 & 1.19 & - & - & - & - & - & - & - & - \\
\hline
\end{tabular}

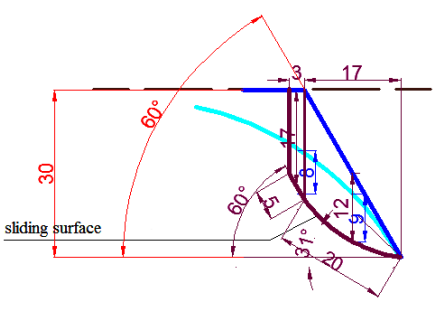

Fig. 1. Scheme for calculating the bench stability in weathered rocks of the hanging wall at $H=30 \mathrm{~m}, \alpha=60^{\circ}$



Fig. 2. Scheme for calculating the bench stability in unweathered rocks of the hanging wall at $H=30 \mathrm{~m}, \alpha=70^{\circ}$

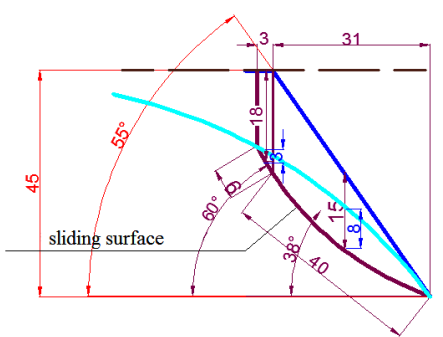

Fig. 3. Scheme for calculating the bench stability in weathered rocks of the hanging wall at $H=45 m, \alpha=55^{\circ}$

of damped jointing leads to a sharp decrease in the stability safety factor (to $\eta=1.19$ ), which increases the risk of unsafe mining, including the location of people and mechanisms under such benches.

3. Loss of stability and violation of the integrity of the entire slope, as calculations show, are manifested with the use of doubled and tripled benches when setting the slope into the final position, with the following parameters (height $\times$ angle of inclination) $30 \mathrm{~m} \times 70^{\circ}, 30 \mathrm{~m} \times 80^{\circ}, 45 \mathrm{~m} \times 55^{\circ}$ and $45 \mathrm{~m} \times$ $\times 80^{\circ}$ in the weathered lying rocks, which may also be associ-
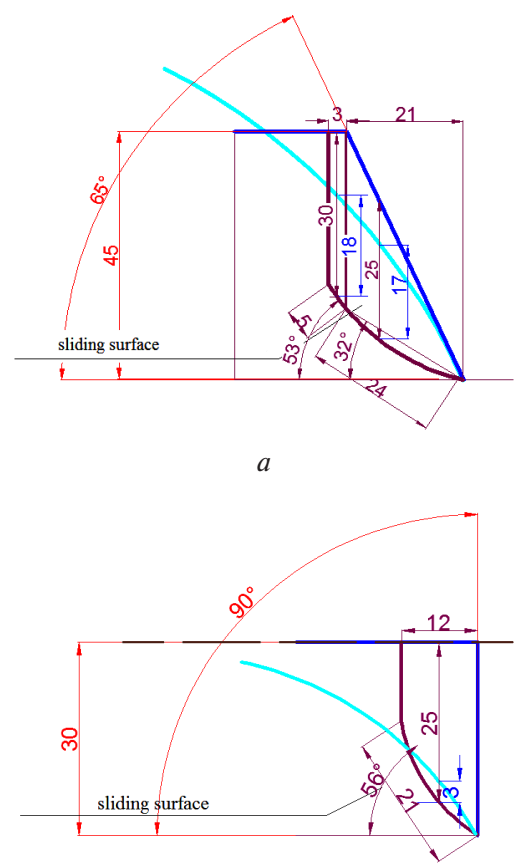

$b$

Fig. 4. Scheme for calculating the bench stability in unweathered rocks of the hanging wall at:

$a-H=45 m, \alpha=65 ; b-H=30 m, \alpha=90^{\circ}$

ated with the presence of the Main Fault. It should be noted that the indicators of the stability factor of the benches with design parameters of $30 \mathrm{~m} \times 60^{\circ}$ in the lying side do not meet the regulatory requirements $[11,12]$.

4. Loss of stability safety is also observed when using benches with the following parameters (height $\times$ angle of inclination): $30 \mathrm{~m} \times 700,30 \mathrm{~m} \times 800,45 \mathrm{~m} \times 650$ and $45 \mathrm{~m} \times 800$ in unweathered rocks, the stability factor is higher than in weathered rocks but its value does not correspond to the normative one. A significant loss of stability of rocks indicates the risks of ensuring the mining production safety.

Conclusions. There are considered possible options for refining the underground and near-shore reserves of the Oleniy Ruchey deposit under the conditions of mining development within the mining allotment. The performed mining-geometric analysis of the considered options shows that option 3 is the most rational with the lowest overburden ratio satisfying the condition of equality of the ore mining cost of by underground and open methods, and equal to $12 \mathrm{~m}^{3} / \mathrm{m}^{3}$.

The purpose of the subsoil user in the modern world is to reduce costs by reducing the volume of overburden operations, 
which can be achieved by stepping up the angles of sides of slopes and benches. In order to ensure the board safety, to increase the level of mining operations safety in highly fractured rocks and with the presence of the Main Fault, where the lying side carries the entire transport system, the authors have carried out a number of calculations and constructions that indicate an unacceptable increase in the height of the bench to $45 \mathrm{~m}$ and its slope more than 55 and $65^{\circ}$ for weathered and unweathered species, respectively, when setting the board to the final position. At this it is also not allowed to increase the slopes of benches by more than 60 and $70^{\circ}$ for weathered and unweathered species, respectively, which is confirmed by geomechanical calculations.

The studies have been carried out within the research work, economic contract No. 73-646 dated 01/06/2017.

\section{References.}

1. Sakantsev, G.G., Sakantsev, M.G., Cheskidov, V.I., \& Norri, V. K. (2014). Improving the development of deep deposits based on the optimization of their opening elements and quarry parameters. FTPRPI, (4), 117-123. https://doi. org/10.1134/S1062739114040097.

2. Cheskidov, V.I., Norri, V.K., Zaitsev, G.D., Botvinnik, A. A., Bobylsky, A. S., \& Reznik, A. V. (2014). Improving the Efficiency of Technologies for Open-cast Mining of Solid Mineral Fields. FTPRPI, (5), 107-123. https://doi. org/10.1134/S1062739114050081.

3. Lobanov, E.A., Chaikin, D.A., \& Menshikov, P.Yu. (2018). Development of technological solutions for the opening and mining of adjacent rock mass and pit reserves of apatite-nepheline ores. Fundamental and applied sciences in mining, 5(1), 88-93. 4. Kozyrev, A.A., Semenov, I. E., \& Avetisyan, I. M. (2015). Geomechanical feasibility of safe mining of joining zones in the Yuksporskoye field. Mining Informational and analytical bulletin, 84-92.

5. Kalyuzhny, A.S. (2016). Determination of the parameters of the disturbed zone and the volume of potential dumps for the conditions of the Oleniy Ruchey quarry. Mining Informational and analytical bulletin, (7), 403-412.

6. Rybin, V.V., Potapov, D.A., \& Kalyuzhny, A.S. (2014). Zoning the quarry field at the Oleniy Ruchey deposit by depth using the geomechanical classification of Professor D. Lobshire. Problems of Subsoil Use, (1), 44-52.

7. Reed, J., \& Stacy, P. (Eds.) (2015). Guidelines for the design of the pit career edges. (Translation from English). Yekaterinburg: Provoved.

8. Guidelines for determining the angles of inclination of the edges, slopes of shelves and dumps of the quarries while construction and exploitation (1972). Leningrad: All-Union Scientific Research Institute of Mining Geomechanics and Surveying (VNIMI). Retrieved from https://meganorm.ru/Index2/1/4294853/4294853734.htm.

9. SNiP 11-7-81* "Construction in seismic areas." (2014). Moscow: Ministry of Construction and Housing and Communal Services of the Russian Federation. Retrieved from http://sniprf.ru/razdel-2/II-7-81.

10. Kalyuzhny, A. S., \& Zemtsovsky, A. V. (2017). Study of the stress-strain state of an array of rocks in the vicinity of a quarry excavation at the Oleniy Ruchey deposit. In Proceedings of the Fersmanovskaya Scientific Session of the Mining Institute of the Kola Scientific Center of the Russian Academy of Sciences, (pp. 278-282).

11. Kozyrev, A.A., Zhukova, S.A., Samsonov, A. V., \& Volkov, A. V. (2015). Methodical principles for taking natural factors into account when assessing the technogenic seismicity of the Khibiny massif. Mining Informational and analytical bulletin, 56-64.

12. Kozyrev, A.A., Semenova, I.E., \& Zemtsovskiy, A.V. (2017). Conquerous Deposits Under Tectonic Stresses Investigation of Geomechanical Features. Mining Informational and analytical bulletin, 191, 324-331. https://doi.org/10.1016/j. proeng.2017.05.188.

\section{Розробка технологічних рішень відпрацювання прибортових і підкар'єрних запасів з урахуванням геомеханічної оцінки родовища}

\author{
Н. А. Немова ${ }^{1}$, Д. Таханов ${ }^{2}$, Б. Хусан ${ }^{2}$, А. Жумабекова ${ }^{2}$
}

1 - Інститут гірничої справи, Сибірське відділення наук, м. Новосибірськ, Російська Федерація, е-таil: nemovanataly@mail.ru

2 - Карагандинський державний технічний університет, м. Караганда, Республіка Казахстан, e-mail: takhanov80@ $\underline{\text { mail.ru }}$

Мета. Оцінка варіантів розкриття й відпрацювання запасів верхнього ярусу апатит-нефелінового родовища «Оленячий струмок» та розроблення технологічних piшень 3 урахуванням проведених геомеханічних розрахунків стійкості уступів і бортів як на граничному контуpi, так і при зміні проектних значень параметрів уступів, борту кар'єру та коефіцієнта запасу стійкості для встановлення їх граничних, максимально допустимих за умовою стійкості, значень.

Методика. Пошук технологічних рішень відпрацювання заснований на методі гірничо-геометричного аналізу верхнього ярусу родовища, порівняння, узагальнення, систематизації, аналітичних розрахунків, 3-D параметричного моделювання, тривимірного чисельного моделювання напружено-деформованого стану та стійкості масиву гірських порід методом скінченних елементів.

Результати. За результатами досліджень запропоновано оптимальний розвиток гірських робіт за варіантом, що передбачає мінімальний коефіцієнт розкриву. Рекомендовані параметри укосів бортів кар'єру та їх елементів на граничному контурі й відпрацювання родовища за варіантом, що передбачає максимально можливе залучення до відпрацювання прибортових і підкар'єрних запасів в існуючих кордонах гірничого відводу кар'єра.

Наукова новизна. Полягає в обгрунтуванні застосування раціональної технології розвитку гірничих робіт за варіантом, що передбачає мінімальний коефіцієнт розкриву, а також можливих схем розвитку гірничих робіт при відпрацюванні прикар'єрних запасів з оцінкою можливості внутрішнього отвалоутворения при доопрацюванні кар'є ра.

Практична значимість. Проведені розрахунки показали, що для умов лежачого борту нормативний коефіцієнт запасу стійкості уступів на граничному контурі може бути забезпечений тільки в тому випадку, якщо вони заоткашуются за поверхнями ослаблення, підрізування яких недопустиме.

Ключові слова: борт, уступ, прибортові, підкар'єрні, прикар'єрні, запаси, напружено-деформований стан, стійкість, система розробки

\section{Разработка технологических решений отработки прибортовых и подкарьерных запасов с учетом геомеханической оценки месторождения}

\section{Н. А. Немова ${ }^{1}$, Д. Таханов ${ }^{2}$, Б. Хусан ${ }^{2}$, А. Жумабекова $a^{2}$}

1 - Институт горного дела, Сибирское отделение наук, г. Новосибирск, Российская Федерация, e-mail: nemovanataly@mail.ru

2 - Карагандинский государственный технический университет, г. Караганда, Республика Казахстан, е-mail: takhanov80@mail.ru 
Цель. Оценка вариантов вскрытия и отработки запасов верхнего яруса апатит-нефелинового месторождения «Олений ручей» и разработка технологических решений с учетом проведенных геомеханических расчетов устойчивости уступов и бортов как на предельном контуре, так и при изменении проектных значений параметров уступов, борта карьера и коэффициента запаса устойчивости для установления их предельных, максимально допустимых по условию устойчивости, значений.

Методика. Поиск технологических решений отработки основан на методе горно-геометрического анализа верхнего яруса месторождения, сравнения, обобщения, систематизации, аналитических расчетов, 3-D параметрического моделирования, трехмерного численного моделирования напряженно-деформированного состояния и устойчивости массива горных пород методом конечных элементов.

Результаты. По результатам исследований предложено оптимальное развитие горных работ по варианту, предусматривающему минимальный коэффициент вскрыши. Рекомендованы параметры откосов бортов карьера и их элементов на предельном контуре и отработка месторождения по варианту, который предусматривает максимально возможное вовлечение в отработку прибортовых и подкарьерных запасов в существующих границах горного отвода карьера.

Научная новизна. Заключается в обосновании применения рациональной технологии развития горных работ по варианту, предусматривающему минимальный коэффициент вскрыши, а также возможных схем развития горных работ при отработке прикарьерных запасов с оценкой возможности внутреннего отвалообразования при доработке карьера.

Практическая значимость. Проведенные расчеты показали, что для условий лежачего борта нормативный коэффициент запаса устойчивости уступов на предельном контуре может быть обеспечен только в том случае, если они заоткашиваются по поверхностям ослабления, подрезка которых недопустима.

Ключевые слова: борт, уступ, прибортовые, подкарьерные, прикарьерные, запасы, напряженно-деформированное состояние, устойчивость, система разработки

Recommended for publication by V. F. Demin, Doctor of Technical Sciences. The manuscript was submitted 15.04.19. 